Review

\title{
Effectiveness of Family Empowerment towards Diet Compliance and Family Independence in Caring for Family Members with Diabetes Mellitus: A Systematic Review
}

\author{
Angga Miftakhul Nizar ${ }^{1}$, Kusnanto $^{* 1}$, Lilik Herawati ${ }^{2}$ \\ ${ }^{1}$ Faculty of Nursing, Universitas Airlangga, Surabaya, Indonesia \\ ${ }^{2}$ Faculty of Medicine, Universitas Airlangga, Surabaya, Indonesia \\ (*kusnanto@fkp.unair.ac.id)
}

\begin{abstract}
Diabetes mellitus has now become a major problem in non-communicable diseases whose prevalence continues to increase. Lack of family independence and client non-compliance with the diet program greatly affects blood sugar levels. This study needs to evaluate the effectiveness of family empowerment towards diet compliance and family independence in caring for family members with diabetes mellitus. A systematic review searched five electronic databases (Scopus, sciencedirect, pubmed, research gate, and google scholar) with the last ten years (2011-2021). The quality of the articles used in this study was assessed using the Joanna Briggs Institute Guideline. The prism protocol is also used to review each journal. We found 15 studies out of a total of 5,865 studies that discussed family empowerment in increasing family independence and dietary adherence in family members suffering from diabetes mellitus. Family empowerment is one method that is quite effective in increasing family independence and adherence to diet programs. There are six articles (40\%) that state that planned behavior theory is effective in increasing family independence and dietary adherence to family members suffering from diabetes mellitus. From all the articles analyzed, there are several effective theories to empower families to change the behavior of family independence and individual diet compliance, namely the theory of planned behavior. However, this study is not strong enough to provide an assessment that family empowerment based on the theory of planned behavior and empowerment is the best way to increase independence, therefore further research is needed.
\end{abstract}

Key words: Diabetes Mellitus, Compliance or Adherence Dietary, Family Empowerment, Theory of Planned Behavior

https://doi.org/10.33860/jik.v15i1.435

(C) 2021 by the authors. Submitted for possible open access publication under the terms and conditions of the Creative

Commons Attribution (CC BY SA) license (https://creativecommons.org/licenses/by-sa/4.0/).

\section{INTRODUCTION}

Diabetes mellitus has now become a major problem in non-communicable diseases whose prevalence continues to increase ${ }^{1}$. DM is also called the mother of disease because DM is the parent of various other diseases such as heart disease, hypertension, stroke, kidney failure, blindness, and amputation of the feet ${ }^{2}$. DM cannot be cured, but blood sugar levels can be controlled ${ }^{3}$. DM can be well controlled by diet, exercise, and anti-diabetic drug therapy ${ }^{4}$. Diet and exercise arrangements are the main things that support the therapy program for patients with diabetes mellitus. If these two things are done well, primary and secondary treatment programs will be carried out optimally 5. According to data from the International Diabetes Federation (IDF), DM sufferers have reached around 463 million people, and with a death rate of around 3.2 million people, placing DM as one of the diseases that does not have the sixth rank with the most mortality in the world ${ }^{6}$. Indonesia ranks sixth in the world as a country with the highest number of DM sufferers. DM is the seventh leading cause of death in the world ${ }^{7}$.

The intervention program from the government in efforts to manage DM disease through primary service units, namely Pusat Kesehatan Masyarakat (Puskesmas) or Health 
Centre Service, includes the Prolanis Program, Older Adult Posyandu for routine health checks for the older adults, and Posbindu Penyakit Tidak Menular (PTM) or Non-Communicable Disease for screening health status and risk behavior of people at productive age ${ }^{8}$. Treatment and management programs for DM disease that focus on the family have not been appropriately applied to date. Lack of family independence and client non-compliance with the diet program significantly affects the instability of blood sugar levels ${ }^{9}$. This is reasons for the increase in the prevalence of chronic diseases, especially DM, every year in several developed countries, especially in developing countries such as Indonesia ${ }^{10}$.

Various efforts to manage noncommunicable DM diseases that have been carried out are deemed ineffective. This is because the increase in DM patients continues, and it is found that more than half of DM patients at Health Center do not comply with the diet program so that other effort are needed to improve dietary adherence to DM patients, namely empowerment models family ${ }^{11}$. Family empowerment has been proven effective in increasing family independence in several other diseases. Even so, family empowerment interventions through a nursing theory approach need to be studied based on relevant studies. Therefore it is necessary to conduct an in-depth systematic study to test family empowerment nursing approaches to improve dietary compliance and family independence with diabetes mellitus..

\section{METHOD}

\section{Study Design}

A systematic review without metaanalysis was carried out for this study. This review followed the steps that elements for Preferred Reporting Items for Systematic Reviews and Meta-Analyses (PRISMA) statement ${ }^{12}$.

\section{Data Sources and Searches}

Five databases were collected by Scopus, Ebsco, PubMed, ProQuest, and Science Direct published between 2016 and 2020. The article's scope was limited to randomized controlled trials (RCTs) and protocol, human studies, and English publications. The researchers develop search terms to collect items related to selfmanagement intervention ${ }^{13}$. The databases search used the following terms (diabetes mellitus OR diabetes mellitus type 2) AND (compliance or adherence dietary) AND (family empowerment or empowerment) AND (diet compliance or family independence) ${ }^{14}$. A comprehensive search strategy has been shown in figure 1.

\section{Eligibility Criteria}

Patients who had been diagnosed with diabetes mellitus were eligible for this review. This study only targeted patients categorized by age group $>16$ years, and data for patients with T2DM will be extracted. T2 diabetes is hyperglycemia which is initially insulin resistance ${ }^{15}$. This type is managed effectively and supported by education and a healthy lifestyle, combined with medication as a requirement ${ }^{16}$. All subjects in the intervention group used family empowerment interventions, but the approach in nursing theory varied. Meanwhile, the exclusion criteria, namely the experimental group, did not meet the basic scientific requirements, and the study results did not include a target value ${ }^{17}$. The outcome measure of this review is dietary adherence or family independence ${ }^{18}$. Secondary outcomes are changes in clinical outcomes and healthrelated quality of life ${ }^{19}$.

\section{Type of Intervention}

The intervention that researchers identified as research data was family empowerment which was defined in multidefinitions, and there was no standard system for classifying it ${ }^{20}$. The World Health Organization (WHO) states that empowering families can provide health services that are more effective in overcoming chronic diseases ${ }^{21}$. This study focuses on using family empowerment interventions to improve dietary adherence or family independence based on the nursing theory approach.

\section{Data Extraction}

The researcher inferentially extracted the data from each article. Data were extracted using narrative analysis to reveal data synthesis, including the characteristics of the study, participants, interventions, and results ${ }^{22}$. The following characteristics report individual studies, such as publication details and methods. The intervention describes the content and characteristics of family empowerment, nursing theory approaches, family roles, and family responses ${ }^{23}$.

\section{Data Synthesis}

Qualitative and quantitative analyses were used for this review. The results presented narratively based on each outcome. 


\section{RESULTS}

In the initial searching the databases, there were 5,865 articles. After removing duplicates and screen the report, 15 articles were finally enrolled in the study (Table 1). Table 1 also showed that the papers were published between 2015 and 2020, with most articles published in 2020 (30.8\%).

Of the 15 articles that have been analyzed, various research designs include randomized controlled trials, quasiexperiments, prospective randomized studies, and case studies. The articles obtained were randomized controlled trials (RCT design), namely four articles. A total of nine articles used a cross-sectional design, and the rest used quasi-experiment design. Participants used in articles vary with a maximum sample size of 991 respondents with an average sample rate in research articles of more than 200 respondents. There are various nursing approaches used in this articles, with most of them use the theory of planned behavior (TPB) with a percentage of $40 \%$. Table 2 showed that there were several studies ranged from moderate and high quality. JBI tool indicated the most of the studies have good quality (11 studies), and only three studies have a moderate bias.

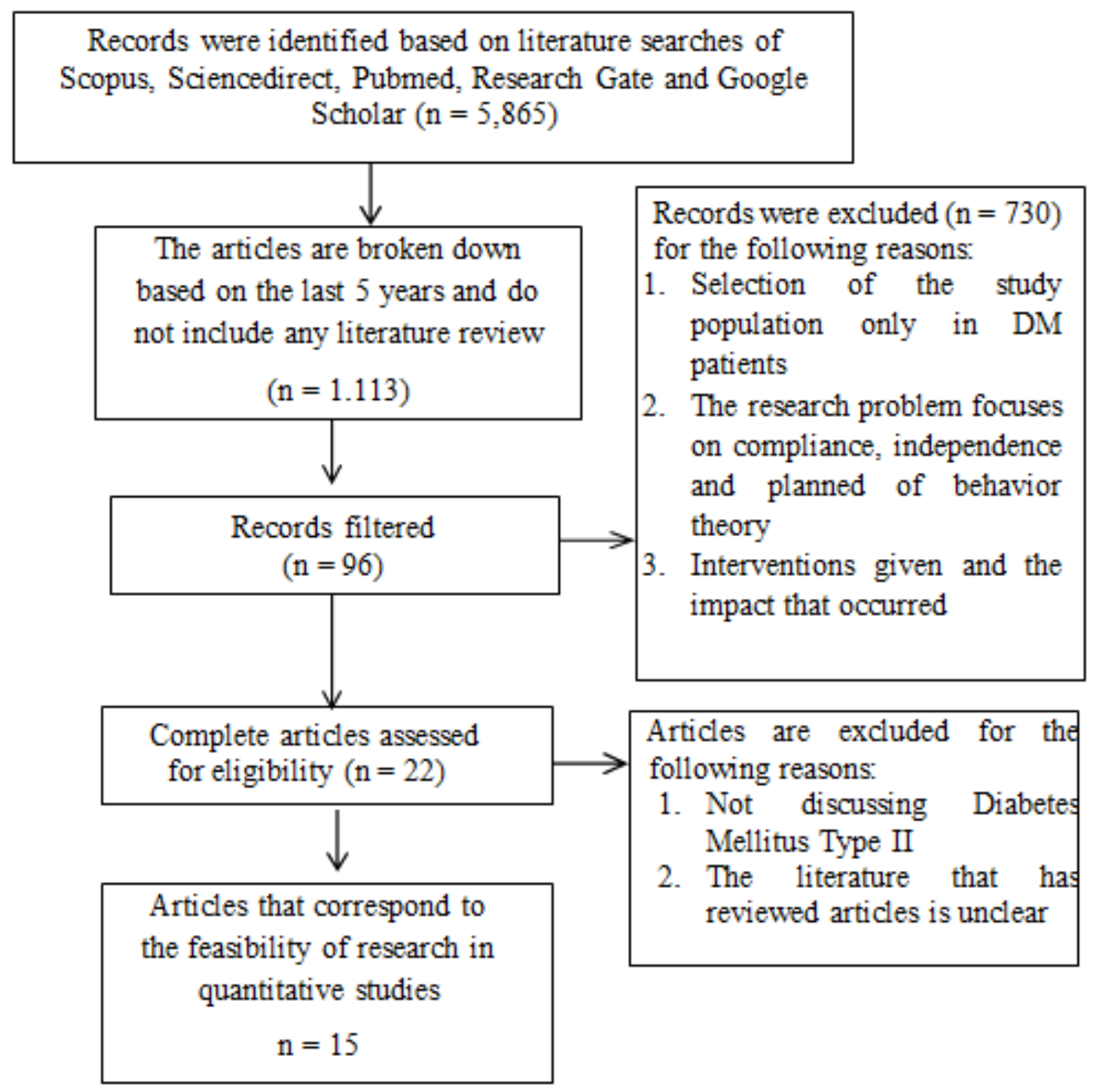

Figure 1. Flow chart of the study identification process 
Table 1. Summarize of selected studies

\begin{tabular}{|c|c|c|}
\hline No & Tittle & DSVIA Method \\
\hline 1 & $\begin{array}{l}\text { Adherence to self care } \\
\text { practices and } \\
\text { empowerment of people } \\
\text { with diabetes mellitus: a } \\
\text { randomized clinical } \\
\text { trial }\end{array}$ & $\begin{array}{l}\text { Design : Randomized Control Trial } \\
\text { Sample: } 183 \text { responden digunakan pada } \\
\text { kelompok ini. Kelompok kontrol } \\
\text { menggunakan } 111 \text { responden, sedangkan } \\
\text { kelompok perlakuan menggunakan } 72 \\
\text { responden. } \\
\text { Variables: independent: age, gender, } \\
\text { education level, marital status, occupation, } \\
\text { duration of suffering from diabetes } \\
\text { Dependent variable: Hb1c, MHN, Diabetes } \\
\text { mellitus self-care support } \\
\text { Instruments: Dalam penelitian } \\
\text { menggunakan instrumen Adherence to Self } \\
\text { care practice for DM (ESM demographic data } \\
\text { (ie, province, gender, age, education and } \\
\text { occupation), Hbalc examination, diabetes } \\
\text { questionnaire sheet Empowerment Scale } \\
\text { Short Form (DES SF). } \\
\text { Analysis: penelitian ini menggunakan uji } \\
\text { pearson, uji mann whitney u test, uji T } \\
\text { berpasangan dan uji wilcoxon sign rank test }\end{array}$ \\
\hline 2 & $\begin{array}{l}\text { Dietary knowledge } \\
\text { among adults with type } 2 \\
\text { diabetes }- \text { kingdom of } \\
\text { Saudi Arabia } \\
\text { Source : }{ }^{25}\end{array}$ & $\begin{array}{l}\text { Design: cross sectional study } \\
\text { Sample: } 350 \text { respondents with type } 2 \text { diabetes } \\
\text { mellitus } \\
\text { Variables: Dependent: Length of suffering } \\
\text { from diabetes, family history, smoking } \\
\text { behavior, BMI, diagnosis, and the treating } \\
\text { doctor. Independent: The respondent's level of } \\
\text { knowledge about dietery knowledge } \\
\text { Instruments: using a valid and reliable self- } \\
\text { prepared questionnaire comprising of } 21 \\
\text { questions } \\
\text { Analysis: Mann Whitney U Test }\end{array}$ \\
\hline
\end{tabular}

Based on the statistical test, it was found that the $\mathrm{P}$ value was $<0.001$, thus indicating a significant decrease in the hemoglobin glycation score. In the self-care and empowerment statistical test, the $\mathrm{P}$ value in the treatment group was $<0.001$, so that there was an increase in the self-care and empowerment compliance score. So that in this study, it was concluded that there was an increase in client participation in disease management, increased empowerment, increased self-care compliance such as a healthy and regular diet, physical activity and exercise as well as regular monitoring of blood sugar levels..

In this study, it is known that adult respondents who suffer from diabetes mellitus in the Kingdom of Saudi Arabia have less knowledge about diet. Poor knowledge about diet, especially in the consumption of carbohydrates and determining the type of food consumed. Diet management is an important instrument in controlling blood sugar levels, so that a poor understanding of the diet will lead to uncontrolled blood sugar levels. Family empowerment can be used to increase client knowledge about diet management.

\begin{tabular}{|c|c|c|c|}
\hline 3 & $\begin{array}{l}\text { Peer-Led } \\
\text { empowerment based } \\
\text { approach to self man } \\
\text { agement efforts in } \\
\text { diabetes (PLEASED) : } \\
\text { Source : }{ }^{26}\end{array}$ & $\begin{array}{l}\text { Design: Randomized Controlled Trial } \\
\text { Sample: } 106 \text { respondents to type } 2 \text { diabetes } \\
\text { research in Africa and the American } \\
\text { community } \\
\text { Variable: Dependents: Group } 13 \text { month } \\
\text { diabetes self management education program } \\
\text { (DSME). Group of } 2 \text { ongoing diabetes self } \\
\text { management support (DSMS). Independent: } \\
\text { Hba1c levels, secondary outcomes such as } \\
\text { Lipid, LDL, HDL, BP, BMI, diabetes distress, } \\
\text { diabetes social support } \\
\text { Instruments: a } 17 \text {-item diabetes distress scale, } \\
\text { biophysiological examination. Analysis: } \\
\text { Spearman chorelations }\end{array}$ & $\begin{array}{l}\text { In this study, it was shown that the } \\
\text { peer support group showed an } \\
\text { increase in the main risk factors } \\
\text { for CVD while in the control } \\
\text { group there was a decrease. The } \\
\text { peer support group significantly } \\
\text { lowered blood pressure levels. } \\
\text { Body mass index, and lower total } \\
\text { cholesterol levels in the blood } \\
\text { when compared with the DSME } \\
\text { group without empowerment. }\end{array}$ \\
\hline 4 & $\begin{array}{l}\text { Can a modified theory } \\
\text { of planned behavior } \\
\text { explain the effects of } \\
\text { empowerment } \\
\text { education for people }\end{array}$ & $\begin{array}{l}\text { Design: longitudinal design study } \\
\text { Sample: } 365 \text { respondents with type } 2 \text { diabetes } \\
\text { mellitus Variable: Factors that influence } \\
\text { psychological empowerment based on theory } \\
\text { of planned behavior }\end{array}$ & $\begin{array}{l}\text { Based on the results of statistical } \\
\text { tests, the P value was } 0.04 \text {. So that } \\
\text { there is an effect of PEP } \\
\text { empowerment on sports activity } \\
\text { behavior and skills in doing foot }\end{array}$ \\
\hline
\end{tabular}




\begin{tabular}{|c|c|c|c|}
\hline & $\begin{array}{l}\text { with type } 2 \text { diabetes? } \\
\text { Source : }{ }^{27}\end{array}$ & $\begin{array}{l}\text { Instrument: Chinese Health Literacy Scale for } \\
\text { Diabetes, basic psychometric properties of the } \\
\text { Chinese Risk, Perception Survey for } \\
\text { Developing Diabetes, diabetes self-efficacy, } \\
\text { Attitude, subjective, intention. } \\
\text { Analysis: Dilakukan pengujian menggunakan } \\
\text { Structural Equation modeling, Chi square test, } \\
\text { root mean error of approximation, } \\
\text { standardized root mean residual, Tucker } \\
\text { index }\end{array}$ & $\begin{array}{l}\text { care, where the relationship } \\
\text { between the two is mediated } \\
\text { through behavioral intention. }\end{array}$ \\
\hline 5 & $\begin{array}{l}\text { Predicting Stage of } \\
\text { Exercise Among } \\
\text { Patients with Type } 2 \\
\text { Diabetes : A Test of the } \\
\text { Extended Theory of } \\
\text { Planned Behavior } \\
\text { Source: }{ }^{11}\end{array}$ & $\begin{array}{l}\text { Design: cross sectional study } \\
\text { Sample: } 791 \text { respondents with type II diabetes } \\
\text { mellitus } \\
\text { Variable: Factors that influence the exercise } \\
\text { stage in type } 2 \text { DM patients based on theory of } \\
\text { planned behavior } \\
\text { Instruments: TPB Scales, observation stage } \\
\text { of exercise, } \\
\text { Analysis: Kruskal wallis, WLSMV, Chi } \\
\text { Square, RMSEA, CFI, TLI, WRMR }\end{array}$ & $\begin{array}{l}\text { This study shows that there is a } \\
\text { strong correlation of self-identity, } \\
\text { descriptive norms, and perceived } \\
\text { behavioral control of one's } \\
\text { intentions. So that in increasing the } \\
\text { client's intention to start doing sports } \\
\text { and physical activities can increase } \\
\text { self-identity, descriptive norms and } \\
\text { PBC. }\end{array}$ \\
\hline 6 & $\begin{array}{l}\text { A test of theory of } \\
\text { planned behavior in } \\
\text { type II diabetes } \\
\text { adherence: role of } \\
\text { leading role of } \\
\text { perceived behavioral } \\
\text { control } \\
\text { Source : }\end{array}$ & $\begin{array}{l}\text { Design: cross sectional study } \\
\text { Sample: } 90 \text { respondents with type II DM who } \\
\text { were selected through convenient sampling. } \\
\text { Variable: Dependents: attitudes, intention, } \\
\text { diabetes duration, food supply difficulty, } \\
\text { constant, subjective norms, PBC. } \\
\text { Independent: Intention, adherence behavior } \\
\text { Instruments: TPB tools, perceived behavioral } \\
\text { control (PBC), behavioral intentions, and } \\
\text { behavior of type II diabetes questionnaire } \\
\text { Analysis: Chi square, Confidance interval }\end{array}$ & $\begin{array}{l}\text { In this study, it is revealed that a } \\
\text { person's behavior is influenced by } \\
\text { the intention to regulate an attitude, } \\
\text { perspective and subjective norms. } \\
\text { So that in making an intervention to } \\
\text { improve behavior in clients with } \\
\text { type II diabetes mellitus, it is } \\
\text { necessary to pay attention to } \\
\text { aspects of perceived behavioral } \\
\text { control, subjective norms, and } \\
\text { intentions. }\end{array}$ \\
\hline 7 & $\begin{array}{l}\text { Improved patient } \\
\text { empowerment, } \\
\text { patient motivation, } \\
\text { and adherence to } \\
\text { medical treatment } \\
\text { programs in } \\
\text { uncontrolled type } 2 \\
\text { diabetes patients } \\
\text { Source : }{ }^{10}\end{array}$ & $\begin{array}{l}\text { Design: RCT research design } \\
\text { Sample: } 97 \text { respondents with type II DM } \\
\text { Variable: } \\
\text { Dependent: } \\
\text { In this study, it was divided into a control } \\
\text { group and an intervention group. The } \\
\text { intervention group was provided with online } \\
\text { consultation services, with doctors, nurses, } \\
\text { and nutrition workers. In addition, if } \\
\text { something is unclear, clients can come } \\
\text { directly to consult offline. Meanwhile, the } \\
\text { control group was given services as usual. } \\
\text { Independent: Empowerment, motivation, and } \\
\text { medical adherence } \\
\text { Instruments: Questionnaire to assess the } \\
\text { characteristics of health care climate (HCCQ), } \\
\text { Questionnaire to identify self-regulation on } \\
\text { medication (TSRQ), Percaived Competence } \\
\text { in diabetes (PCD), self-care activity } \\
\text { questionnaire (SDSCA), WHO Well Being } \\
\text { Index, description of barriers found when } \\
\text { suffering from diabetes mellitus (PAID-5), } \\
\text { HBa1c, BP, and BMI } \\
\text { Analysis: interquartile range, standard } \\
\text { deviations, Kruskal Wallis test }\end{array}$ & $\begin{array}{l}\text { The results of this study found that } \\
\text { there was an increase in the goal } \\
\text { setting of clients with diabetes } \\
\text { mellitus in regulating diet and } \\
\text { physical activity patterns, and } \\
\text { there was an increase in autonomy } \\
\text { support in the intervention group. } \\
\text { This is different when compared } \\
\text { to the control group which was } \\
\text { relatively unchanged. Despite this } \\
\text { increased autonomy support, and } \\
\text { goal setting in diet and exercise, } \\
\text { the intervention group was no } \\
\text { better than the control group in } \\
\text { terms of reducing blood sugar } \\
\text { levels. }\end{array}$ \\
\hline 8 & $\begin{array}{l}\text { The effect of giving the } \\
\text { intervention } \\
\text { "implementation } \\
\text { intention" to increase }\end{array}$ & $\begin{array}{l}\text { Design: A randomized, parallel-group, single- } \\
\text { center controlled trial } \\
\text { Sample: } 90 \text { respondents who suffer from type } \\
\text { II diabetes }\end{array}$ & $\begin{array}{l}\text { The results of this study indicated } \\
\text { that the intervention group } \\
\text { showed increased adherence to the } \\
\text { oral anti-diabetes treatment }\end{array}$ \\
\hline
\end{tabular}




\begin{tabular}{|c|c|c|c|}
\hline & $\begin{array}{l}\text { adherence to the use of } \\
\text { oral anti-diabetes in type } \\
2 \text { diabetes patients in } \\
\text { Brazil } \\
\text { Source : }{ }^{29}\end{array}$ & $\begin{array}{l}\text { Variable: Dependent: implementation } \\
\text { intention intervention. Independent: } \\
\text { adherence to consumption of OAD, diabetes } \\
\text { related distress and glycemic control } \\
\text { Instruments: Sociodemographic data, } \\
\text { Instrument for the Global Evaluation of } \\
\text { Medication Adherence (IAGAM), National } \\
\text { Glycohemoglobin Standardization Program } \\
\text { (NGSP), Diabetes Distress Scale (B-DDS), } \\
\text { Analysis: Chi square test, Mann Whitney test, } \\
\text { fisher exact, multivariate regression }\end{array}$ & $\begin{array}{l}\text { regimen }(\mathrm{p}<0.0001) \text {, glycemic } \\
\text { control ( } \mathrm{p}<0.0001) \text { and diabetes- } \\
\text { related disorders (p <0.0001) } \\
\text { relative to CG. Thus the } \\
\text { implementation intention } \\
\text { intervention improves adherence } \\
\text { to the oral antidiabetic treatment } \\
\text { regime, which has a positive effect } \\
\text { on blood glucose levels and } \\
\text { diabetes-related pressure. }\end{array}$ \\
\hline 9 & $\begin{array}{l}\text { Predisposing factors for } \\
\text { type } 2 \text { diabetes sufferers } \\
\text { and complication } \\
\text { prevention behavior in } \\
\text { African Americans in } \\
\text { Floridar through } \\
\text { phenomic family health } \\
\text { history based on theory } \\
\text { of planned behavior }\end{array}$ & $\begin{array}{l}\text { Design: cross sectional study } \\
\text { Sample: } 394 \text { respondents Variable: } \\
\text { Variable: Independent; psychological } \\
\text { intervention.Dependent mental health } \\
\text { instruments: Diabetes Risk Factor Survey } \\
\text { Tools, } \\
\text { Analysis: Logistic regression }\end{array}$ & $\begin{array}{l}\text { In this study, it was found that } \\
\text { perceived behavioral control or } \\
\text { PBC is an important element in the } \\
\text { formation of an intention. } \\
\text { Perceived behavioral control that } \\
\text { is felt by a person will } \\
\text { significantly influence behavior in } \\
\text { preventing the occurrence of type } \\
2 \text { diabetes mellitus. }\end{array}$ \\
\hline
\end{tabular}

\begin{tabular}{|c|c|c|c|}
\hline 10 & $\begin{array}{l}\text { Predicting Noninsulin } \\
\text { Antidiabetic Drug } \\
\text { Adherence Using a } \\
\text { Theoretical Framework } \\
\text { Based on the Theory of } \\
\text { Planned Behavior in } \\
\text { Adults With Type } 2 \\
\text { Diabetes } \\
\text { Source : } 14\end{array}$ & $\begin{array}{l}\text { Design: A prospective study } \\
\text { Sample: Respondents in this study were } 340 \\
\text { respondents with type } 2 \text { diabetes mellitus } \\
\text { Variable: factors that influence medication } \\
\text { adherence based on theory of planned } \\
\text { behavior } \\
\text { Instrument: questionnaire modified by Theory } \\
\text { of planned behavior } \\
\text { Analysis: Local regression wirh statistical } \\
\text { analysis system (SAS), spearman chorelation }\end{array}$ & $\begin{array}{l}\text { This study shows that the TPB is a } \\
\text { good tool for predicting intention to } \\
\text { comply and adherence to NIAD in } \\
\text { the future, particularly in past non- } \\
\text { NIAD followers. TPB is a frame } \\
\text { work theory that is relevant to } \\
\text { differentiating past adherents from } \\
\text { non-believers in the past when } \\
\text { someone wants to implement } \\
\text { NIAD adherence enhancement } \\
\text { interventions. }\end{array}$ \\
\hline 11 & $\begin{array}{l}\text { Predicting Diabetic } \\
\text { Self-Care } \\
\text { Management Based } \\
\text { On The Theory Of } \\
\text { Planned Behavior } \\
\text { Among Elderly With } \\
\text { Type } 2 \text { Diabetes In } \\
\text { Thailand } \\
\text { Source: }\end{array}$ & $\begin{array}{l}\text { Design: Crossectional study Sample: } 212 \\
\text { respondents with type } 2 \text { diabetes mellitus in } \\
\text { Thailand } \\
\text { Variable: Self care management, Behavioral } \\
\text { Intention (BI) and Perceived behavioral } \\
\text { control (PBC) } \\
\text { Instruments: Demographic Characteristics, } \\
\text { TPB tools, and diabetic self care management } \\
\text { behaviors (DSCM) } \\
\text { Analysis: Pearson product Moment, and } \\
\text { Multiple regression analysis }\end{array}$ & $\begin{array}{l}\text { The results illustrate that there is a } \\
\text { significant influence and a strong } \\
\text { correlation between subjective } \\
\text { norms, behavioral control felt by } \\
\text { clients with diabetes mellitus on } \\
\text { the intention to carry out diabetes } \\
\text { mellitus treatment behavior. } \\
\text { Behavioral control was the most } \\
\text { important variable that had the } \\
\text { most significant influence in } \\
\text { predicting intention }(p<0.01) \text { and } \\
\text { self-care management }(p<0.01) \text {. }\end{array}$ \\
\hline 12 & $\begin{array}{l}\text { Psychosocial factors } \\
\text { associated toward } \\
\text { adherence to non- } \\
\text { insulin antidiabetes } \\
\text { treatments } \\
\text { Source : }{ }^{9}\end{array}$ & $\begin{array}{l}\text { Design: Cross sectional survey } \\
\text { Sample: } 991 \text { respondents with type II diabetes } \\
\text { mellitus } \\
\text { Variable: Psychosocial factors that affect } \\
\text { respondents' compliance in consuming NIAD } \\
\text { Instrument: TPB questionnaire, Morisky } \\
\text { Medication Adherence Scale based on web } \\
\text { wuestionnaire } \\
\text { Analysis: logistic regression }\end{array}$ & $\begin{array}{l}\text { This study shows that the } \\
\text { behavioral control felt by } \\
\text { respondents, habits, age, duration } \\
\text { of suffering, has a significant } \\
\text { effect on the dietary compliance of } \\
\text { clients with diabetes mellitus. }\end{array}$ \\
\hline
\end{tabular}




\begin{tabular}{|c|c|c|c|}
\hline 13 & $\begin{array}{l}\text { Modelling of } \\
\text { diabetes knowledge, } \\
\text { attitudes, self- } \\
\text { management, and } \\
\text { quality of life: a } \\
\text { cross-sectional study } \\
\text { with an Australian } \\
\text { sample } \\
\text { Source: }{ }^{15}\end{array}$ & $\begin{array}{l}\text { Design: Cross sectional study } \\
\text { Sample: } 291 \text { respondents with diabetes } \\
\text { mellitus } \\
\text { Variable: Knowledge of diabetes mellitus } \\
\text { behavior, self management and quality of life } \\
\text { Instruments: diabetes knowledge scale } \\
\text { questionnaire sheet), diabetes-19 integration } \\
\text { scale attitude questionnaire sheet, self- } \\
\text { management questionnaire sheet, } \\
\text { questionnaire sheet that examines aspects of } \\
\text { diet, exercise, blood glucose testing, foot care, } \\
\text { and quality of life for clients with diabetes } \\
\text { mellitus. } \\
\text { Analysis: The statistical test of this study uses } \\
\text { path analysis, T test, Structural Equation } \\
\text { Modeling (SEM), Root Mean Square Error of } \\
\text { Approximation (RMSEA) test, Goodness of } \\
\text { Fit (GFI) test. }\end{array}$ & $\begin{array}{l}\text { This study proves that improving } \\
\text { self-management in increasing } \\
\text { adherence to diet, exercise and } \\
\text { activity patterns has a significant } \\
\text { effect on improving the quality of } \\
\text { life for people with type } 2 \text { diabetes } \\
\text { mellitus in Australia. }\end{array}$ \\
\hline 14 & $\begin{array}{l}\text { The role of } \\
\text { perceptions of } \\
\text { disease: Self-efficacy, } \\
\text { depression rates, and } \\
\text { self-care activities in } \\
\text { Jordanians with type } \\
2 \text { diabetes } \\
\text { Source : }{ }^{31}\end{array}$ & $\begin{array}{l}\text { Design: Crosssectional survey } \\
\text { Sample: } 220 \text { respondents Dm type II } \\
\text { Variables: Self-care behavior, perceptions of } \\
\text { diabetes, feelings of depression, support from } \\
\text { social groups, factors of religiosity, individual } \\
\text { spiritual coping and self-efficacy } \\
\text { Instruments: The research instruments } \\
\text { included a diabetes management self-efficacy } \\
\text { scale, a short diabetes perception } \\
\text { questionnaire, a 9-item patient health } \\
\text { questionnaire, a social support instrument, a } \\
\text { religious and spiritual coping subscale } \\
\text { questionnaire. } \\
\text { Analysis: The statistical test in this study uses } \\
\text { the structure equation modeling to determine } \\
\text { the relationship between the two variables. }\end{array}$ & $\begin{array}{l}\text { The results of this study indicate } \\
\text { that the empowerment program } \\
\text { has a significant effect on } \\
\text { improving self-skills. } \\
\text { Psychosocial factors such a } \\
\text { perception of disease, depressive } \\
\text { symptoms, self-efficacy, social } \\
\text { support, religiosity, spiritual } \\
\text { coping have a correlation in } \\
\text { improving self-care for clients } \\
\text { with type } 2 \text { diabetes mellitus. }\end{array}$ \\
\hline 15 & $\begin{array}{l}\text { Identification of social } \\
\text { support for people } \\
\text { with diabetic foot } \\
\text { ulcers } \\
\text { Source: }{ }^{16}\end{array}$ & $\begin{array}{l}\text { Design: Cross sectional servey } \\
\text { Sample: } 240 \text { respondents with diabetic foot } \\
\text { ulcers } \\
\text { Variables: perceived social support and } \\
\text { factors affecting diabetic wounds. } \\
\text { Instruments: Data collection including } \\
\text { demographic, clinical, self-report, and } \\
\text { perceived social support, measured by } \\
\text { Multidimensional Scale of Perceived Social } \\
\text { Support (MSPSS) } \\
\text { Analysis: Kruskal Wallis, Mann Whitney, } \\
\text { Spearman rho correlation coefficient }\end{array}$ & $\begin{array}{l}\text { Based on the results of statistical } \\
\text { tests between social support and } \\
\text { the level of information, the level } \\
\text { of family information, and } \\
\text { behavior in examining diabetes } \\
\text { wounds, the p value was }<0.05 \text {. } \\
\text { Social support has a significant } \\
\text { influence on several of these } \\
\text { factors. }\end{array}$ \\
\hline
\end{tabular}


Table 2. Critical appraisal

\begin{tabular}{|c|c|c|c|c|c|c|c|c|c|c|c|c|c|c|c|}
\hline \multirow{2}{*}{ No } & \multicolumn{13}{|c|}{ JBI critical appraisal/ Number of item } & \multirow{2}{*}{ Total } & \multirow{2}{*}{ Quality } \\
\hline & 1 & 2 & 3 & 4 & 5 & 6 & 7 & 8 & 9 & 10 & 11 & 12 & 13 & & \\
\hline 1 & $\mathrm{Y}$ & $\mathrm{Y}$ & UN & $\mathrm{Y}$ & $\mathrm{Y}$ & $\mathrm{Y}$ & $\mathrm{Y}$ & $\mathrm{Y}$ & $\mathrm{Y}$ & $\mathrm{Y}$ & $\mathrm{Y}$ & $\mathrm{Y}$ & $\mathrm{Y}$ & 92,3 & High \\
\hline 2 & $\mathrm{Y}$ & $\mathrm{Y}$ & $\mathrm{Y}$ & $\mathrm{Y}$ & $\mathrm{Y}$ & UN & $\mathrm{Y}$ & $\mathrm{Y}$ & - & - & - & - & - & 87,5 & High \\
\hline 3 & $\mathrm{Y}$ & $\mathrm{Y}$ & UN & $\mathrm{Y}$ & UN & $\mathrm{Y}$ & $\mathrm{Y}$ & $\mathrm{Y}$ & $\mathrm{Y}$ & $\mathrm{Y}$ & $\mathrm{Y}$ & $\mathrm{Y}$ & $\mathrm{Y}$ & 84,6 & High \\
\hline 4 & $\mathrm{Y}$ & $\mathrm{Y}$ & $\mathrm{Y}$ & $\mathrm{N}$ & $\mathrm{N}$ & $\mathrm{N}$ & $\mathrm{Y}$ & $\mathrm{Y}$ & $\mathrm{Y}$ & $\mathrm{Y}$ & $\mathrm{Y}$ & $\mathrm{Y}$ & $\mathrm{Y}$ & 76,9 & High \\
\hline 5 & $\mathrm{Y}$ & $\mathrm{Y}$ & $\mathrm{Y}$ & $\mathrm{Y}$ & $\mathrm{Y}$ & UN & $\mathrm{Y}$ & $\mathrm{Y}$ & - & - & - & - & - & 87,5 & High \\
\hline 6 & $\mathrm{Y}$ & $\mathrm{Y}$ & $\mathrm{Y}$ & $\mathrm{Y}$ & UN & UN & $\mathrm{Y}$ & $\mathrm{Y}$ & - & - & - & - & - & 75 & Moderate \\
\hline 7 & $\mathrm{Y}$ & $\mathrm{Y}$ & $\mathrm{Y}$ & UN & $\mathrm{Y}$ & $\mathrm{Y}$ & $\mathrm{Y}$ & $\mathrm{Y}$ & $\mathrm{Y}$ & $\mathrm{Y}$ & UN & $\mathrm{Y}$ & $\mathrm{Y}$ & 92,3 & High \\
\hline 8 & $\mathrm{Y}$ & $\mathrm{Y}$ & $\mathrm{Y}$ & UN & $\mathrm{Y}$ & $\mathrm{Y}$ & $\mathrm{Y}$ & $\mathrm{Y}$ & $\mathrm{Y}$ & $\mathrm{Y}$ & $\mathrm{Y}$ & $\mathrm{Y}$ & $\mathrm{Y}$ & 69,2 & Moderate \\
\hline 9 & $\mathrm{Y}$ & $\mathrm{Y}$ & $\mathrm{Y}$ & $\mathrm{Y}$ & $\mathrm{Y}$ & UN & $\mathrm{Y}$ & $\mathrm{Y}$ & - & - & - & - & - & 87,5 & High \\
\hline 10 & $\mathrm{Y}$ & $\mathrm{Y}$ & $\mathrm{Y}$ & UN & $\mathrm{Y}$ & UN & $\mathrm{Y}$ & $\mathrm{Y}$ & $\mathrm{Y}$ & $\mathrm{Y}$ & $\mathrm{Y}$ & $\mathrm{Y}$ & $\mathrm{Y}$ & 69,2 & Moderate \\
\hline 11 & $\mathrm{Y}$ & $\mathrm{Y}$ & $\mathrm{Y}$ & $\mathrm{Y}$ & UN & UN & $\mathrm{Y}$ & $\mathrm{Y}$ & - & - & - & - & - & 75 & Moderate \\
\hline 12 & $\mathrm{Y}$ & $\mathrm{Y}$ & $\mathrm{Y}$ & $\mathrm{Y}$ & $\mathrm{Y}$ & $\mathrm{N}$ & $\mathrm{Y}$ & $\mathrm{Y}$ & - & - & - & - & - & 87,5 & High \\
\hline 13 & $\mathrm{Y}$ & $\mathrm{Y}$ & $\mathrm{Y}$ & $\mathrm{Y}$ & UN & $\mathrm{Y}$ & $\mathrm{Y}$ & $\mathrm{Y}$ & - & - & - & - & - & 87,5 & High \\
\hline 14 & $\mathrm{Y}$ & $\mathrm{Y}$ & $\mathrm{Y}$ & $\mathrm{Y}$ & $\mathrm{Y}$ & UN & $\mathrm{Y}$ & $\mathrm{Y}$ & - & - & - & - & - & 87,5 & High \\
\hline 15 & $\mathrm{Y}$ & $\mathrm{Y}$ & $\mathrm{Y}$ & $\mathrm{Y}$ & $\mathrm{N}$ & UN & $\mathrm{Y}$ & $\mathrm{Y}$ & - & - & - & - & - & 87,5 & High \\
\hline
\end{tabular}

The scores $:$ high $=>75 \%$, moderate $=50-74 \%$, low $=50 \%$;

$\mathrm{N}=0 ; \mathrm{UN}=0 ; \mathrm{Y}=1 ; \mathrm{NA}=0 \mathrm{~N}=$ no;

$\mathrm{UN}=$ Unclear; Y = Yes; NA = Not Aplicable

\section{DISCUSSION}

From all articles obtained and analyzed, most of the articles discussed family adherence to a diet program based on family support ${ }^{23}$. Through the empowerment approach, it provides allows the exchange of new information by sharing experiences ${ }^{20}$ as well as active participation through activities in the learning process which are carried out with a focus on finding new meanings for the event that is being felt ${ }^{32}$. Family empowerment has the influence and effectiveness to increase family independence and client adherence to therapy and diet programs. The family empowerment referred to in this article is family empowerment based on the theory of planned behavior ${ }^{28}$, and family empowerment is based on analysis of client and family background factors ${ }^{18}$, personal factors ${ }^{14}$, social factors, and information factors from the family of patients suffering from DM ${ }^{33}$. The use of behavior change based on a protocol will encourage others to understand and understand important aspects and a sense of responsibility for what has been done in self-care efforts ${ }^{15}$. Dietary control management carried out by diabetic clients has a very important role in controlling blood sugar ${ }^{9}$; however, it is still found that most 
clients are not aware of this diet problem ${ }^{34}$.

One of the ways to increase patient knowledge about diet management is to use a family empowerment approach ${ }^{30}$. Through the family empowerment approach, the facilitator can provide materials to increase patient understanding and provide awareness to diabetics about the importance of maintaining diet and diet ${ }^{35}$. Family empowerment is an effective family approach to increase independence and dietary compliance in patients with diabetes mellitus ${ }^{36}$. Through the planned behavior theory approach, it is found that intention has a significant influence on perceived behavioral control ${ }^{9}$ between the two there is a direct relationship that mutually affects each other ${ }^{7}$. Based on previous research, it is proven that family empowerment influences and effectiveness in increasing family independence and client compliance in therapy and diet programs ${ }^{24}$. Family empowerment in this discussion is focused on the theory of planned behavior and empowerment focuses on analyzing background factors, personal factors, social factors, and information factors from the families of patients suffering from $\mathrm{DM}^{37}$.

One of the strong predictors of a behavior based on the theory of planned behavior is the existence of perceived behavioral control ${ }^{38}$. With the finding of a significant correlation between $\mathrm{PBC}$ and behavior, $\mathrm{PBC}$ is an important element that needs to be considered in improving diabetes mellitus management so that it becomes better. ${ }^{39}$, this is in line with the previous theory and explanation ${ }^{40}$. Facilitators or health workers must facilitate and pay more attention to the perception of control that is felt by the main patient in dietary behavior and activity patterns, this is because each patient has a different relationship so that it cannot be generalized ${ }^{30}$. Other writings include the policies carried out for routine blood glucose, routine medication, dietary management, physical activity and self-care ${ }^{41}$. Family empowerment carried out by health workers must also pay attention to the multiculture in a patient and family such as social, cultural, demographic, financial and other supporting factors ${ }^{42}$. The use of family empowerment will optimally improve treatment if family independence is carried out with a more holistic approach to managing diabetes mellitus adherence behaviors, taking into account the socio-cultural dynamics that occur in many medical conditions ${ }^{28}$.

\section{CONCLUSION}

In conclusion, this systematic review found that family empowerment can effectively increase the role of the family in providing care for patients with diabetes mellitus. Several nursing approaches, one of which uses the theory of planned behavior, states that it effectively increases self-reliance, family roles, and dietary compliance. Based on the results of the literature study that the researchers conducted, it proved that family independence and treatment program adherence could be achieved better by using family empowerment methods based on theory of planned behavior and empowerment. However, this study is not strong enough to provide an assessment that family empowerment based on the theory of planned behavior and empowerment is the best way to increase independence and based, therefore further research is needed to prove the effectiveness of using this approach.

\section{ACKNOWLEDGMENT}

The authors would like to thank the Master of Nursing Study Program, Faculty of Nursing, Universitas Airlangga for providing the opportunity to present this study

\section{REFERENCE}

1. Kusnanto K, Sari NPWP, Harmayetty H, Efendi F, Gunawan J. Self-care model application to improve self-care agency, selfcare activities, and quality of life in patients with systemic lupus erythematosus. Journal of Taibah University Medical Sciences. 2018;13(5):472-8.

2. Ricci E, Cutting KF. Evaluating a native collagen matrix dressing in the treatment of chronic wounds of different aetiologies: A case series. Journal of Wound Care. 2016;25(11):670-8.

3. Hasanah U, Makhfudli M, Ni'Mah L, Efendi F, Aurizki GE. Peer Group Support on the Treatment Adherence of Pulmonary Tuberculosis Patients. In: 4th International Conference on Tropical and Coastal Region Eco Development, ICTCRED 2018. Faculty of Nursing, Universitas Airlangga, Surabaya, Indonesia: Institute of Physics Publishing; 2019.

4. Efendi F, Nursalam N, Kurniati A, Gunawan J. Nursing qualification and workforce for the Association of Southeast Asian Nations Economic Community. Nursing Forum. 
2018;53(2):197-203.

5. Cortez DN, Reis IA, Torres C. Adherence to self-care practices and empowerment of people with diabetes mellitus: a randomized clinical trial *. 2017;1-8.

6. WHO. Profil of Indonesia [Internet]. 2016 [cited 2019 Aug 28]. Available from: https://www.who.int/nmh/countries/idn_en.p df

7. Sami W, Alabdulwahhab KM, Rashid M, Hamid A, Alasbali TA, Alwadani F Al, et al. Dietary Knowledge among Adults with Type 2 Diabetes - Kingdom of Saudi Arabia.

8. Tang TS. Peer-Led, Empowerment-Based Approach to Self-Man- agement Efforts in Diabetes (PLEASED): A Randomized Controlled Trial in an African American Community. 2015;27-35.

9. Guénette L, Breton MC, Guillaumie L, Lauzier S, Grégoire JP, Moisan J. Psychosocial factors associated with adherence to non-insulin antidiabetes treatments. Journal of Diabetes and its Complications. 2016;30(2):335-42.

10. Varming AR, Rasmussen LB, Husted GR, Olesen K, Grønnegaard C, Willaing I. Improving empowerment, motivation, and medical adherence in patients with poorly controlled type 2 diabetes: A randomized controlled trial of a patient-centered intervention. Patient Education and Counseling. 2019;102(12):2238-45.

11. Gao M, Chen X, Sun X, Wang F, Fan L, Sun $X$. Predicting stage of exercise among patients with type 2 diabetes: A test of the extended theory of planned behavior. Patient Preference and Adherence. 2020;14:277-85.

12. Donizetti D, São-joão $T$, Cornélio $M$, Jannuzzi F, Rui M, Sousa D, et al. Patient Education and Counseling Effect of an " implementation intention intervention on adherence to oral anti-diabetic medication in Brazilians with type 2 diabetes. 2019;

13. Seaborn C, Suther S, Lee T, Kiros GE, Becker A, Campbell E, et al. Utilizing genomics through family health history with the theory of planned behavior: Prediction of type 2 diabetes risk factors and preventive behavior in an African American Population in Florida. Public Health Genomics. 2016;19(2):69-80.

14. Zomahoun HTV, Moisan J, Lauzier S, Guillaumie L, Grégoire JP, Guénette L. Predicting Noninsulin Antidiabetic Drug Adherence Using a Theoretical Framework Based on the Theory of Planned Behavior in Adults with Type 2 Diabetes. Medicine (United States). 2016;95(15):1-10.

15. Kueh YC, Morris T, Borkoles E, Shee H. Modelling of diabetes knowledge, attitudes, self-management, and quality of life: A cross- sectional study with an Australian sample. Health and Quality of Life Outcomes. 2015;13(1):1-11.

16. Laopoulou F, Kelesi M, Fasoi G, Vasilopoulos G, Polikandrioti M. Perceived Social Support in Individuals with Diabetic Foot Ulcers: A Cross-sectional Survey. Journal of Wound, Ostomy and Continence Nursing. 2020;47(1):65-71.

17. Sugiyama T, Steers WN, Wenger NS, Duru OK, Mangione CM. Effect of a communitybased diabetes self- management empowerment program on mental healthrelated quality of life: a causal mediation analysis from a randomized controlled trial. 2015;1-9.

18. Bays HE, Bazata DD, Clark NG, Iii JRG, Green AJ, Lewis SJ, et al. Prevalence of selfreported diagnosis of diabetes mellitus and associated risk factors in a national survey in the US population : SHIELD ( Study to Help Improve Early evaluation and management of risk factors Leading to Diabetes ). 2004;9:19.

19. Ayele AA, Emiru YK, Tiruneh SA, Ayele BA, Gebremariam AD, Tegegn HG. Level of adherence to dietary recommendations and barriers among type 2 diabetic patients: a cross-sectional study in an Ethiopian hospital. 2018;7:1-7.

20. Lourdes M De, Zille B. Study of influence of a model guidance about the laboratory tests and disease in knowledge and selfmanagement of patients with type $2 \mathrm{DM}$. 2015;7(Suppl 1):1-2.

21. Mogre V, Johnson NA, Tzelepis F, Shaw J, Paul C. Adherence to self-care behaviours and associated barriers in type 2 diabetes patients of low-and middle-income countries: a systematic review protocol. 2017;1-6.

22. Nguyen KT, Thanh B, Diep T, Nguyen VDK, Lam H Van, Tran KQ. A cross-sectional study to evaluate diabetes management, control and complications in 1631 patients with type 2 diabetes mellitus in Vietnam ( DiabCare Asia ). 2020;40(March):70-9.

23. Rathish D, Hemachandra R, Premadasa T, Ramanayake S, Rasangika C, Roshiban R, et al. Comparison of medication adherence between type 2 diabetes mellitus patients who pay for their medications and those who receive it free: a rural Asian experience. 2019;9:1-8.

24. Macedo MML, Cortez DN, Santos JC dos, Reis IA, Torres H de C. Adherence to self-care practices and empowerment of people with diabetes mellitus: A randomized clinical trial. Revista da Escola de Enfermagem. 2017;51:1-8.

25. Sami W, Alabdulwahhab KM, Hamid MRA, 
Alasbali TA, Alwadani F Al, Ahmad MS. Dietary knowledge among adults with type 2 diabetes-kingdom of Saudi Arabia. International Journal of Environmental Research and Public Health. 2020;17(3).

26. Tang TS, Funnell MM, Sinco B, Spencer MS, Heisler M. Peer-led, empowerment-based approach to self-management efforts in diabetes (PLEASED): A randomized controlled trial in an African American community. Annals of Family Medicine. 2015;13:S27-35.

27. Lin CY, Cheung MKT, Hung ATF, Poon PKK, Chan SCC, Chan CCH. Can a modified theory of planned behavior explain the effects of empowerment education for people with type 2 diabetes? Therapeutic Advances in Endocrinology and Metabolism. 2020;11:112.

28. Dilekler İ, Doğulu C, Bozo Ö. A test of theory of planned behavior in type II diabetes adherence: The leading role of perceived behavioral control. Current Psychology. 2019;

29. Trevisan DD, São-João T, Cornélio M, Jannuzzi F, de Sousa MR, Rodrigues R, et al. Effect of an 'implementation intention' intervention on adherence to oral anti-diabetic medication in Brazilians with type 2 diabetes. Patient Education and Counseling. 2020;103(3):582-8.

30. Wongrith P. Predicting diabetic self-care management based on the theory of planned behavior among elderly with type 2 diabetes in Thailand. Diabetes Mellitus. 2019;22(4):367-76.

31. Al-Amer R, Ramjan L, Glew P, Randall S, Salamonson Y. Self-Efficacy, Depression, and Self-Care Activities in Adult Jordanians with Type 2 Diabetes: The Role of Illness Perception. Issues in Mental Health Nursing. 2016;37(10):744-55.

32. Sweileh WM, Zyoud SH, Abu RJ, Deleq MI, Enaia MI. Influence of patients disease knowledge and beliefs about medicines on medication adherence : findings from a crosssectional survey among patients with type 2 diabetes mellitus in Palestine. 2014;1-8.

33. Ting CY, Ahmad S, Adruce Z, Hassali MA, Ting H, Lim CJ, et al. Correction to : Effectiveness and sustainability of a structured group-based educational program ( MEDIHEALTH ) in improving medication adherence among Malay patients with underlying type 2 diabetes mellitus in Sarawak State of Malaysia : study protocol o. 2019;19-20.

34. Yuk E, Wan F, Siu C, Fung C, King C, Wong H. Effectiveness of a multidisciplinary risk assessment and management programme diabetes mellitus ( RAMP-DM ) on patient- reported outcomes. Endocrine. 2017;416-26.

35. Wong CKH, Lam CLK, Wan EYF, Chan AKC, Frank CHP, William WKC. Evaluation of patient-reported outcomes data in structured diabetes education intervention : 2year follow-up data of patient empowerment programme. Endocrine. 2016;422-32.

36. Yasmin F, Nahar N, Banu B, Ali L, Sauerborn $\mathrm{R}$, Souares A. The influence of mobile phonebased health reminders on patient adherence to medications and healthy lifestyle recommendations for effective management of diabetes type $2:$ a randomized control trial in Dhaka, Bangladesh. 2020;1-12.

37. Rumaseuw R, Berliana SM, Nursalam N, Efendi F, Pradanie R, Rachmawati PD, et al. Factors Affecting Husband Participation in Antenatal Care Attendance and Delivery. In: M.A. R, editor. 3rd International Conference on Tropical and Coastal Region Eco Development 2017. Badan Pusat Statistik, Supiori District of Papua Province, Indonesia: Institute of Physics Publishing; 2018.

38. Ulrich D, Smeets R, Unglaub F, Wöltje M, Pallua N. Effect of oxidized regenerated cellulose/collagen matrix on proteases in wound exudate of patients with diabetic foot ulcers. Journal of Wound, Ostomy and Continence Nursing. 2011;38(5):522-8.

39. Kassahun T, Gesesew H, Mwanri L, Eshetie T. Diabetes related knowledge, self-care behaviours and adherence to medications among diabetic patients in Southwest Ethiopia: a cross-sectional survey. BMC Endocrine Disorders. 2016;1-11.

40. Saryono S, Taufik A, Proverawati A, Efendi F. Dietary supplementation of Phoenix dactylifera L. Seeds decreases proinflammatory mediators in CCl4-induced rats. Journal of HerbMed Pharmacology. 2019;8(3):212-7.

41. Firmansyah Y. Pemberdayaan anak sekolah guna mewujudkan tangguh bencana tanah longsor melalui sosialisasi, di kecamatan Simpenan, kabupaten Sukabumi. Jurnal Universitas Padjadjaran. 2017;1(1):6-9.

42. Goharshenasan P, Amini S, Atria A, Abtahi H, Khorasani G. Topical application of honey on surgical wounds: A randomized clinical trial. Forschende Komplementarmedizin. 2016;23(1):12-5. 